\title{
Urgensi Perlunya Pembaharuan Hukum Acara Pidana Nasional di Indonesia yang Lebih Responsif
}

\author{
M. Zen Abdullah \\ Dosen Tetap Yayasan Fakultas Hukum Unbari \\ Correspondence email: zen.abdullah@unbari.ac.id
}

\begin{abstract}
Abstrak. Sesuai dengan latar belakang penelitian tentang "Urgensi Perlunya Pembaharuan Hukum Acara Pidana Nasional di Indonesia Yang Lebih Responsif", sehingga dapat diambil rumusan masalah yang akan diba-has, yaitu ; Apakah diperlukan suatu pembaruan hukum acara pidana nasional di Indonesia yang lebih responsif dalam menghadapi perkem-bangan hukum dan era globalisasi saat ini Urgensi dilakukan pembaharuan hukum acara pidana nasional di Indonesia yang lebih responsif, karena hukum acara pidana (KUHAP) dipandang tidak sesuai lagi dengan perubahan sistem ketatanegaraaan dan perkembangan hukum dalam masyarakat, terutama dalam praktik penanganan perkara tindak pidana yang menjadi petugas para penegak hukum untuk menyelesaikan perkaranya secara baik dan adil, dan yang kedua perkembangan hukum dan perubahan peta politik yang dibarengi dengan perkembangan ekonomi, transportasi dan tehnologi yang global berpengaruh pula terhadap makna dan keberadaan substansi KUHAP, sehingga perlu dilakukan pembaruan dengan hukum acara pidana yang lebih akomodatif, responsif dan aspiratif. Dalam rangka penegakan hukum yang berorientasi kepastian hukum dan berdimensi keadilan. Rancangan KUHAP harus dapat memberikan perlindungan dan pengakuan terhadap hak- hak azasi dan membatasi tindakan sewenang- wenang aparat penegak hukum dalam penyelesaian dan penanganan perkara tindak pidana dan dapat beradabtasi dengan tuntutan global, sesuai dengan konvensi yang sudah diratifikasi oleh Indonesia.
\end{abstract}

Kata kunci: urgensi; pembaharuan hukum; pidana

\begin{abstract}
In accordance with the background of research on "urgency need to reform national criminal event law in Indonesia more responsive ", so it can be taken the formulation of problems that will be Diba-has, namely; Is it necessary to update the law of national criminal event in Indonesia that is more responsive in the face of the Perkem-bangan of law and globalization era at present urgency is done renewal of national criminal event law in Indonesia more responsive, Because criminal proceedings Law (KUHAP) is deemed to be inappropriate with changes in the system of governance and legal developments in the community, especially in the practice of handling criminal acts that become officers of law enforcement officials to Complete the work properly and fairly, and the second the development of the law and the change of political map coupled with economic development, transportation and technology that also affects the global meaning and existence of the substance KUHAP, So it needs to be done renewal with a more accommodating, responsive and aspirational criminal event law. In the framework of law enforcement oriented with legal and dimensional justice. The KUHAP draft must be able to provide protection and recognition to the rights of the law and restrict the actions of the legal Officer in the settlement and handling of criminal acts and may be conjoined with global demands, accordance with the conventions that have been ratified by Indonesia.
\end{abstract}

Keywords: urgency; of legal reform; criminal

\section{PENDAHULUAN}

Pembaharuan sistem politik dan produk hukum yang berupa perun-dang- undangan tidak bisa dipungkiri. Undang- undang Nomor 8 Tahun 1981 tentang Kitab Undang- undang Hukum Acara Pidana (KUHAP) me-mang patut dibanggakan karya agung bangsa Indonesia (R. Soesilo, 2004: 1), yang perlu diberikan apresiasi. Kitab Undang- undang ini sudah meru-pakan pembaharuan total dari Kitab Undangundang Hukum Acara Pidana kolonial yang berbentuk Herziene Insland Reglement (HIR).

Dengan KUHAP ini yang terjadi pertama kali di Indonesia adalah kodi-fikasi dan unifikasi hukum yang lengkap, dalam arti seluruh proses pidana dari awal (mencari kebenaran) sampai pada kasasi di Mahkamah Agung, bahkan sampai meliputi peninjauan kembali/herziening (Andi Hamzah, 1987: 5). Sebagai hukum acara pidana yang berisikan ketentuan tata tertib proses penyelesaian penanganan kasus tindak pidana,sekaligus telah memberi legalisasi hak azasi kepada tersangka atau terdakwa untuk mem-bela kepentingannya di depan pemeriksaan aparat penegak hukum. Pengakuan hukum yang tegas akan hak azasi yang melekat pada diri mereka dari tindakan sewenangwenang. KUHAP telah mencoba mengga-riskan tata tertib hukum yang antara lain melepaskan tersangka atau terdakwa maupun keluarganya dari kesengsaraan putus asa dibelantara penegakan hukum yang tak bertepi, karena sesuai dengan jiwa dan se-mangat yang diamantkannya, tersangka atau terdakwa harus diberlakukan berdasarkan nilai- nilai yang manusiawi (M.Yahya Harahap,2004: 6).

Walaupun KUHAP telah memberikan secercah harapan dalam proses penyelesaian dan penanganan suatu tindak pidana dalam sistem peradilan pidana terpadu (criminal justice system). Namun diakui setelah 
berjalan dari tiga dekade, ternyata KUHAP masih terdapat kekurangan dan kelema-han- kelemahan yang ditemukan dalam praktik. KUHAP dipandang tidak sesuai lagi dengan perubahan sistem ketatanegaraaan dan perkembangan hukum dalam masyarakat, sehingga perlu dilakukan pembaruan dengan hukum acara pidana yang lebih responsif. Dalam penjelasan umum Rancangan KUHAP dikemukakan sejumlah indikator yang menunjukkan KUHAP sudah ketinggalan zaman, yang pertama KUHAP masih belum mampu memenuhi kebutuhan hukum dalam masyarakat, terutama dalam praktik penanganan perkara tindak pidana yang menjadi petugas para penegak hukum untuk menyelesaikan perkaranya secara baik dan adil, dan yang kedua perkembangan hukum dan perubahan peta politik yang dibarengi dengan perkembangan ekonomi, transportasi dan tehnologi yang global berpengaruh pula terhadap makna dan keberadaan substansi KUHAP (Chairul Huda, 2009:2). Dengan demikian, hampir 39 tahun telah berlalu sejak pengesahan KUHAP, perkembangan tak dapat dihindari dan sudah demikian pesatnya. KUHAP sebagai produk hukum yang statis tidak dapat lagi mengikuti fleksibilitas kondisi dan situasi yang dinamis, mulai dari perkembangan tehnologi yang ekstraktif hingga pesatnya perkem-bangan bentuk dan modus tindak pidana. Disisi lain terhadap kebutuhan agar cara penanganan tindak pidana tersebut juga tidak mengindahkan perlindungan terhadap hak-hak warga negara.

Dari beberapa indikator kekurangan dan kelemahan- kelemahan substansi (materi/isi) maupun rumusan- rumusan yang terdapat di dalam KUHAP, maka terhadap KUHAP perlu dilakukan pembaruan yang ran-cangannya sudah dimasukkan dalam Program Legislasi Nasional (Prog-lenas) pada tahun 2000- 2004, 2004- 2009, 2009, 2014. Secara kasat mata kelemahan dalam KUHAP memberi ruang secara luas kewenangan aparat penegak hukum, terutama kepada kepolisian dan kejaksaan, kewenangan tersebut tidak diimbangi dengan ruang pengawasan dan akuntabilitas yang dilakukannya,sehingga potensi untuk penyalahgunaan dan korupsi begitu besar dan terbuka lebar, mulai dari penetapan tersangka, penahanan, penghentian penyidikan (SP3), penghentian penuntutan sampai dengan pelaksanaan eksekusi (Miko Susanto,2014:2). KUHAP juga memberi ruang pada subjektivitas dan diskresi aparatur penegak hukum tanpa ada-nya mekanisme uji yang layak. Dengan demikian upaya melakukan pem-baharuan KUHAP dengan menghadirkan skema pengawasan dan pengu-jian, senafas dengan upaya untuk memberantas korupsi, terutama korupsi di sektor pengadilan (judicial corupption).

Dengan demikian, rencana pembaharuan KUHAP ini mendapatkan momentumnya pada tanggal 6 Maret 2013, pemerintah secara resmi me-nyerahkan Rancangan KUHAP yang memuat 286 pasal kepada DPR.
Selanjutnya DPR merspon penyerahan Rancangan tersebut dengan mem-bentuk Panitia Kerja (Panja) untuk membahasnya. Namun hingga saat ini pembahasan Rancangan KUHAP belum mendapat perhatian dan prioritas dalam penyelesaiannya, sedangkan perubahan dan dinamika kehidupan sosial dalam masyarakat terusmenerus berkembang dan berubah seiring dengan kemajuan zaman. Untuk itu betapa penting dilakukan "Revitalisasi Pembaharuan Hukum Acara Pidana Nasional Yang Lebih Responsif"

\section{Perumusan Masalah}

Sesuai dengan latar belakang penelitian tentang "Urgensi Perlunya Pembaharuan Hukum Acara Pidana Nasional di Indonesia Yang Lebih Responsif", sehingga dapat diambil rumusan masalah yang akan dibahas,yaitu ; Apakah diperlukan suatu pembaruan hukum acara pidana nasional di Indonesia yang lebih responsif dalam menghadapi perkem-bangan hukum dan era globalisasi saat ini ?

\section{HASIL DAN PEMBAHASAN}

Urgensi Perlunya Dilakukan Pembaharuan Hukum Acara Pidana Nasional di Indonesia Yang Lebih Responsif

Di dalam penegakan hukum sebagai landasan tegaknya supremasi hukum, tidak saja menghendaki komitmen ketaatan seluruh komponen bangsa terhadap hukum, tetapi mewajibkan aparatur penegak hukum menegakan dan menjamin kepastian hukum. Di dalam menegakan dan menja-min kepastian hukum, tindakan aparatur penegak hukum secara formal harus ada pengaturannya, agar tindakannya tidak kontradiktif dengan Undang- undang. Artinya tidak saja mengacu kepada ketentuan hukum pidana materil tetapi juga mengacu kepada hukum pidana formil yang lazim disebut dengan hukum acara pidana. Hukum acara pidana (hukum pidana formil) mengatur tentang bagaimana negara melalui perangkatnya melak-sanakan haknya untuk menerapkan hukum pidana materil. Hukum acara pidana tertuju kepada dua sasaran pokok (Bambang Poernomo,1999:5), yaitu usaha melancarkan jalannya proses penerapan hukum pidana oleh alat perlengkapan negara yang berwenang dan jaminan hukum bagi setiap orang untuk menghindari tuntutan atau hukuman yang bertentangan dengan hak azasi manusia. Dengan demikian, keberadaan (eksistensi) dari hukum acara pidana sangat dibutuhkan dalam rangka memberikan keter-tiban, ketentraman, kepastian dan keadilan.

Mengingat keberadaan KUHAP yang dilahirkan sejak tahun 1981 hingga saat ini sudah menginjak usia yang ke tahun 39, tentu sangat dira-sakan terdapat beberapa kelemahan dan kekurangan dalam praktiknya, baik substansi/materi yang termuat dalam KUHAP maupun rumusannya, sehingga dirasakan KUHAP tertinggal dibandingkan dengan kecepatan 
perkembangan dan tuntutan hukum dan globalisasi saat ini, dan sudah tentu perlu dilakukan pembaharuan. Pembaharuan KUHAP dilakukan kare-na sudah tidak sesuai lagi dengan perkembangan masyarakat dan kebutu-han hukum negara Indonesia sebagai akibat dari terjadinya perubahan sosial, ekonomi dan hukum akibat kemajuan tehnologi yang sangat pesat terutama di bidang komunikasi, transportasi dan migrasi di dunia dewasa ini.

Pentingnya dilakukan pembaharuan hukum acara pidana (KUHAP), agar tercipta supremasi hukum dengan menuju sistem peradilan pidana terpadu dengan menempatkan penegak hukum pada tugas, fungsi dan wewenangnya dan beradaptasi dengan kemajuan tehnologi, struktur keta-tanegaraa, perkembangan hukum masyarakat serta berbagai konversi internasional yang telah diratifikasi oleh negara Indonesia. Berbagai ratifikasi yang terkait hukum acara pidana dalam konvensi Internasional yang dilakukan oleh pemerintah Indonesia (Miko Susanto S,2014:1) adalah ;

a. Convention Against Torture and Other Cruel, Inhuman or Degrading Treatment or Punishment, yang disahkan dengan Undang- undang Nomor 5 Tahun 1998, tentang pengesahan konvensi menentang penyiksaan dan perlakuan atau penghukuman lain yang kejam, tidak manusiawi atau merendahkan martabat manusia,

b. International covenant on civil and political rights yang disahkan dengan Undang- undang Nomor 12 Tahun 2005 tentang kovenan Internasional hak- hak sipil dan politik, dan

c. United nation convention against corruption yang disahkan dengan Undang- undang Nomor 7 Tahun 2006, tentang konvensi perserikatan bangsa- bangsa anti korupsi.

Berbagai ratifikasi yang dilakukan persoalannya adalah prinsif- prinsif dalam perjanjian internasional serta hukum acara di luar KUHAP belum disesuaikan dengan pengaturan dalam KUHAP. Untuk itu, perlu dilakukan sinkronisasi dan harmonisasi dalam kerangka kodifikasi kitab undang- un-dang hukum acara pidana. Meskipun, perlu diperhatikan bahwa kodifikasi sebagai pengkitaban yang sistematis dan terstruktur bukan berarti meniadakan ketentuan- ketentuan lain di luar kitab undang- undang ter-sebut.

Selain sebagai upaya untuk merespon dan menyesuaikan dengan perkembangan di atas, pembaharuan terhadap KUHAP juga hadir sebagai jawaban atas kebutuhan akan perlindungan hak azasi manusia dan pemberantasan korupsi dalam koridor kesatuan sistem yang dinamakan dengan proses peradilan pidana yang terpadu (the integrated criminal justice system), bukan seakan- akan terpisah satu dengan yang lain.

Dari perspektif hak azasi manusia, KUHAP saat ini sudah jelas tidak optimal dalam memberikan jaminan perlindungan dan pemenuhan hak, baik dalam pengaturan norma maupun pelaksanaannya. KUHAP dibahas dan disyahkan pada konstalasi politik yang bernuansa otoriter serta diselimuti tarik menarik kewenangan antar institusi yang begitu kental. Konsekwensinya adalah perhatian terhadap hak warga negara, baik seba-gai tersangka dan atau terdakwa, saksi maupun korban terabaikan atau dikatakan belum optimal. Perlunya segera dilakukan pembaruan KUHAP didasari dari perjalanan praktik penegakan hukum itu sendiri, khususnya Undang- undang Nomor 8 Tahun 1981 yang belum memadai memberikan perlindungan kepada tersangka/terdakwa, perkembangan sistem peradilan pidana dan proses hukum yang adil (due proces of law). Selain itu, untuk melakukan sinkronisasi aturan hukum acara pidana dengan dilakukan ratifikasi dalam beberapa konvensi internasional tentang hukum acara pidana.

Suatu hal yang mendasar diperlukan adanya pembaruan hukum acara pidana terkait dengan persoalan 'penahanan' yang ada dalam KUHAP, persoalan penahanan telah melahirkan banyak tindakan sewenangwenang dan korup dari penegak hukum akibat mudahnya melakukan tin-dakan penahanan (Wahyudi Djafar, 2015:1). Kendati KUHAP mensya-ratkan adanya syarat objektif dan subyektif, dalam praktiknya syaratsyarat tersebut seringkali diabaikan penegak hukum, dan lebih mengedepankan unsur subjektivitas dalam penahanan. Tidak ada campur tangan pengadilan dalam penahanan menjadikan kepolisian dan kejaksaan sebagai pihak yang diberikan mandat acapkali gampang melakukan penahanan.

Problem lain terkait penahanan adalah lamanya jangka waku pena-hanan yang diatur dalam KUHAP, seseorang yang disangka melakukan suatu tindak pidana dapat ditahan minimal 400 hari, terhitung sejak proses penyidikan hingga kasasi. Mengingat telah banyaknya korban sebagai akibat kesewenangan serta fleksibelnya aturan dalam KUHAP yang berimbas mudahnya aparat penegak hukum untuk merampas kebebasan, maka menjadi keharusan untuk mempercepat dilakukan pembaharuan hukum acara pidana. Selain itu, urgensi dilakukan pembaharuan hukum acara pidana (KUHAP), karena hampir selama 39 tahun belakangan ini daptar persoalan yang ditimbulkan akibat tidak memadainya lagi KUHAP sebagai pedoman hukum acara kian nampak jelas didepan mata. Kasus prita dan kasus jual beli ipad tanpa manual menjadi contoh nyata, betapa tidak lagi sejalannya KUHAP dengan perkembangan zaman, yang meng-hendaki keadilan sebagai bagian penting dari perlindungan hak azasi.

Betapa pentingnya untuk dilakukan pembaharuan KUHAP dilandasi secara filosofis dan sosiologis, mengingat KUHAP yang dilahirkan sejak tahun 1981 secara kasat mata (Romli Atmasasmita,2010:15), celah pengambil kebijakan untuk menggunakan hukum sekedar sebagai alat (mekanis) dengan tujuan memperkuat dan mendahulukan kepentingan kekuasaan 
dari pada kepentingan dan manfaat bagi masyarakat seluasnya. Kesulitan dan hambatan tersebut juga akan sangat rentan terhadap penyalahgunaan kekuasaan baik oleh eksekutif,legislatif maupun yudikatif. Hal ini telah terjadi peristiwa perampasan hak- hak rakyat untuk tujuan- tujuan tertentu.

Kondisi penataan kehidupan masyarakat dan semangat melakukan pembaharuan hukum acara pidana sejak pemerintahan Orde Baru sampai Orde Reformasi terbukti masih jauh dai cita- cita pendiri Repulbik Indonesia sebagaimana diamanatkan oleh Undangundang Dasar 1945. Keadaan ini menurut Satjipto Rahardjo, (2009: 30) hukum senyatanya bukan lagi seba-gai sarana pembaharuan masyarakat, tetapi telah berubah menjadi dark engeneering. Apabila kondisi ini dibiarkan secara berlanjut proses dark engeneering oleh pemegang kekuasaan, akan menimbulkan skeptisme terhadap fungsi dan peranan hukum (hukum acara pidana) di dalam masyarakat. Sebaiknya, menurut teori hukum progresif (Satjipto Rahardjo, 2009: 38), hukum adalah untuk manusia, bukan sebaliknya. Berkaitan dengan hal ini, hukum tidak ada untuk dirinya sendiri, melainkan untuk sesuatu yang lebih luas dan besar, maka setiap kali ada masalah dalam dan dengan hukum (hukum acara pidana), hukumlah yang ditinjau dan diperbaiki serta bukan manusia yang dipaksakan untuk dimaksukkan ke dalam sistem hukum.

Selanjutnya, Satjpto Rahardjo (2009:31), merasakan kegelisahan sesudah merenungkan lebih dari 65 tahun usia negara Republik Indonesia, berbagai rencana nasional telah dibuat untuk mengembangkan hukum (hu-kum acara pidana) di negeri ini, tetapi tidak juga memberikan hasil yang memuaskan, bahkan grafik menunjukkan trend yang menurun. Orang tidak berbicara tentang kehidupan hukum yang makin bersinar, melainkan sebaiknya suram. Dengan demikian, hukum (hukum acara pidana) sepa-tutnya dipandang bukan hanya sebagai perangkat yang harus dipatuhi oleh masyarakat melainkan juga harus dipandang sebagai sarana yang membatasi wewenang dan prilaku aparat penegak hukum dan pejabat publik. Untuk itu,dalam pembaharuan hukum acara pidana (KUHAP), se-baiknya proses pembentukan dan penyusunannya dilakukan dengan me-menuhi beberapa kreteria, yang pertama proses yang mengutamakan tiga prinsif, yaitu partisifasi, transparan dan akuntabel, yang kedua substansi harus jelas, lugas dan sesuai dengan dinamika perkembangan hukum da-lam masyarakat, dengan tujuan dibuat untuk kepentingan masyarakat, bu-kan untuk kepentingan penguasa dan kelompok tertentu (Aria Su-yudi,2009:14).

Dengan berpedoman kepada pembetukan dan penyusunan secara baik dan benar yang memenuhi kreteria di atas, sehingga hukum (hukum acara pidana) yang diperbaharui dimaksud dapat memberikan rasa kepastian dan keadilan. Lahirnya hukum acara pidana nasional yang modern sudah lama didambakan oleh semua orang. Masyarakat menghendaki hukum acara pidana yang dapat memenuhi kebutuhan hukum masyarakat yang sesuai dengan selaras dengan Pancasila dan Undang- undang Dasar 1945, KUHAP boleh dikatakan telah membangkitkan optimisme harapan yang lebih baik dan manusiawi dalam pelaksanaan penegekan hukum.

Ketika praktik peradilan Indonesia menggunakan telekonprensi dan ketika munculnya Undang- undang baru, seperti Undang- undang penga-dilan HAM, Undang- undang pencucian uang, undang- undang terorisme dan lainnya. Kita tidak membantah munculnya berbagai keluhan dan kritik yang ditujukan kepada KUHAP, karena substansi yang ada di dalam KUHAP tidak sesuai lagi dengan perkembangan hukum dan tehnologi, termasuk alat- alat bukti pasal 184 yang diatur dalam KUHAP. Ada bebe-rapa hal yang menyangkut teknologi yang langsung mempengaruhi hukum pidana dan hukum acara pidana, misalnya kemajuan tehnologi komputer, program komputer, SMS,internet, faksimili,email, termasuk dalam penger-tian surat. Jika iya mesti alat bukti di dalam KUHAP berupa surat harus diperluas pengertiannya, sehingga mencakup perkembangan dimaksud. Menghadapi perkembangan tehnologi informasi tersebut, sudah barang tentu ada benarnya untuk mengatakan sebagian rumusan dan standar KUHAP sudah kurang mampu menampung dan menjembatani perma-salahan kongkrit yang muncul dimaksud, sudah sepantasnyalah KUHAP dilakukan pembaharuannya.

Globalisasi dalam segala kehidupan memang semakin meningkat, kita tidak dapat menghindari globalisasi ekonomi, sosial, budaya dan hukum. Saling membantu kerjasama antar negara dalam penegakan hukum se-makin penting, seperti ektradisi, pengembalian aset, pertukaran tahanan dan narapidana sudah diatur dalam PBB. Negara- negara diwajibkan untuk menciptakan peraturan hukum tertentu, seperti money loundering, korupsi, terorisme, dengan demikian semua ini memerlukan penyusunan Undang- undang baru termasuk pembaharuan hukum acara pidana (KUHAP) yang sesuai dan dapat diterima oleh negaranegara di dunia.

KUHAP dalam penerapan masih terdapat kekurangan, oleh karena itu pembaharuan KUHAP tidak bersifat gradual dan menyeluruh, tetapi bersifat parsial di mana dari sisi kebijakan formulasi dan aplikasi yang terjadi dalam praktek penerapannya kurang maksimal dan akomodatif, hendaknya diru-muskan kembali sehingga menjadi lebih aspiratif dalam menjawab tantangan dan perkembangan hukum saat ini. Hal lain yang memerlukan pembaharuan KUHAP, untuk kontek penangkapan dan penahanan, yang diatur pasal 17 dan pasal 21, dalam kenyataan tidak ditemukan jawaban yang memuaskan atas apa yang dimaksud diduga keras dan keadaan yang menimbulkan kekhawatiran, pengujian bukti permulaan dan bukti yang cukup mengundang pertanyaan, ruang subjektif dan parameter 
yang tidak jelas dan mekanisme yang tidak efektif dan optimal, yaitu prapradilan. Pemeriksaan praperadilan jika perkara berjalan menjadikan pemeriksaan praperadilan gugur. Kenyataan di atas, lubang besar sangat merugikan para pihak yang merasa tindakan atas dirinya tidak didasarkan pada pro-fesional dan kecukupan bukti (Miko Susanto :2014:7). Oleh sebab itulah perubahan dengan pembaharuan KUHAP salah satu solusinya.

Sepatutnya dapat dimengerti bahwa urgensi pembaharuan hukum acara pidana (KUHAP), adalah demi kepentingan perlindungan hak azasi manusia sekaligus merupakan upaya pemberantasan korupsi yang saling terpadu antara penegak hukum dan pengadilan. Pembaharuan KUHAP adalah salah satu langkah dalam pembenahanan sistem peradilan pidana terpadu. Bertahan dengan pengaturan KUHAP saat ini, sama dengan melanggengkan potensi penyalahgunaan dan korupsi dalam penegakan hukum. Perlu ada upaya yang efektip dan efisien dalam kerja pem-berantasan korupsi, yaitu dengan mengefektifkan penegakan hukum lainnya dan institusi pengadilan melalui pembaharuan KUHAP.

Indonesia yang menganut sistem penegakan hukum terpadu (criminal justice system) yang merupakan legal sprit dari KUHAP, keterpaduan tersebut secara filosofis adalah suatu instrumen untuk mewujudkan tujuan nasional dari bangsa Indonesia yang telah dirumuskan oleh the founding father dalam Undang- undang dasar 1945, yaitu melindungi masyarakat dalam rangka mencapai kesejahteraan sosial (Chairul Huda,2009:3).

Dalam sistem penegakan hukum terpadu berdasarkan KUHAP yang selama ini kita miliki menganut azas division of function yang memisahkan secara tegas fungsi dan wewenang penyidikan, penuntutan dan pemerik-saan di sidang pengadilan serta pelaksanaan putusan dan penetapan pengadilan yang terintegrasi, menuju kepada sistem peradilan pidana terpadu, tetapi di dalam praktek belum menunjukkan sinergi antar institusi tersebut (Rahman Amin,2014:1). Maraknya kritik terhadap realitas penega-kan hukum terhadap kinerja yang tergabung dalam sistem peradilan pidana terpadu merupakan hal yang wajar. Keprihatinan tersebut harus dilihat sebagai suatu keinginan dari semua pihak supaya terjadi perubahan ke arah yang lebih baik.

Kekecewaan masyarakat terhadap penegak hukum yang sangat mengkhawatirkan adalah hilangnya kepercayaan terhadap penyidik kepo-lisian. Masyarakat tidak mau menyerahkan seorang yang melakukan tindak pidana kepada penyidik kepolisian, masyarakat menghakimi, memproses dan mengeksekusi sendiri orang yang tertangkap tangan. Hal tersebut dilakukan karena masyarakat sudah terlalu banyak melihat bagaimana seorang yang melakukan tindak pidana akhirnya dibebaskan kembali oleh penyidik kepolisian dengan alasan yang diberitakan rata- rata kurang bukti, tidak memenuhi unsur delik sehingga menimbulkan kekecewaan masyara-kat yang melaporkannya. Hal yang mengkhawatirkan urgensi perlunya dilakukan pembaharuan hukum acara pidana (KUHAP), kecenderungan timbulnya bolak balik perkara dalam tahap prapenuntutan, karena fungsi penyidikan terfragmentasi dari fungsi penuntutan (Chairul Huda, 2009 :6). Dalam bidang penegakan hukum, sebenarnya baik kepolisian maupun kejaksaan keduanya merupakan 'law enforcement', sehingga tidak pada tempatnya tidak terkoordinasi satu dengan yang lainnya dengan baik. Azas diferensiasi fungsional yang diatur dalam KUHAP mempunyai kelemahan secara sistematis. Dalam bidang penegakan hukum, seharusnya dari semula arah perkembangan penyidikan dalam direksi penuntut umum, mengingat legal guilt yang harus dibuktikan penuntut umum bersumber dari factual guilt yang ditemukan penyidik.

Terakhir sub sistem pemidanaan terkonsentrasi pada pidana peram-pasan kemerdekaan, terutama pidana penjara dan mengabaikan pada jenis pidana lain. Merebaknya corporate crime yang sanksinya denda dan menjadi masalah hukum jika denda tidak dibayar, sehingga secara teknis pemidanaan hanya terfokus pada pengurus korporasinya, masih belum ditemukan pemecahan yang memadai dalam bidang hukum acara karena KUHAP tidak siap atau disiapkan untuk menghadapi fenomena ini. Ditambah lagi eksekusi pidana denda dan pembayaran uang pengganti yang kurang epektif. Berdasarnya kenyataan di atas, reformasi atau pem-baharuan KUHAP bukan sesuatu hal yang perlu semata- mata, tetapi lebih jauh sudah sangat mendesak (Rahman Amin,2014:2). Pembaharuan hukum acara pidana nasional telah lama menjadi kajian dan pembahasan bagi kalangan akademisi, praktisi dan penegak hukum di Indonesia, Pembangunan atau pembaharuan hukum acara pidana itu tentu sudah menjadi cita- cita bangsa untuk mewujudkan hukum yang adil bagi masya-rakat, mengingat KUHAP yang berlaku saat ini sudah tidak lagi menjawab permasalahan hukum yang ada di Indonesia, khususnya dalam perkembangan terkini yang sudah modern cenderung menimbulkan ketidakpuasan masyarakat dalam penegakan hukum. Perkembangan masyarakat yang semakin modern menimbulkan pergerseran- pergeseran kultur serta nilai- nilai yang ada dalam masyarakat, hal ini acapkali tidak diimbangi dengan hukum yang ada, akibanya masyarakat merasakan ketidakadilan hukum yang berdampak juga ketidakpercayaan terhadap penegak hukum, contohnya saja pada kasus mbok minah yang dilaporkan mencuri tiga buah kakao, sebenarnya tidak manusiawi untuk memperkarakan kasus ini, selain pihak pelapor yang kurang memiliki hati nurani, hal ini juga tentu menyen-tuh sendi- sendi hukum yang tidak bisa dipungkiri akan menimbulkan ketidakadilan mbok minah dipidana dengan pidana percobaan, sudah barang tentu kasus- kasus seperti ini mencoreng dunia hukum yang sering disebut juga tajam kebawah namun tumpul 
keatas. Persoalan ini tidak terlepas dari kelemahan KUHAP yang tidak memadai lagi dengan kultur yang ada di masyarakat (Miko Susanto,2014:4).

Upaya untuk pembangunan atau reformasi hukum acara pidana akan terus bergulir dengan semangat dan ide serta konsep dasar yang pada intinya untuk mewujudkan hukum yang memiliki nurani keadilan, kepastian dan flesibilitas mereka pada masyarakat secara umum, tidak berhenti pada tarap retorika belaka dan juga tidak dilandasi kepentingan untuk penguasa atau golongan tertentu saja. Namun semata- mata keinginan atau harapan mewujudkan keadilan bagi seluruh rakyat Indonesia. Pada akhirnya keberadaan KUHAP atau konsep KUHAP yang baru, diyakini disyahkan dan diberlakukan sebagai hukum positif sehingga dapat membawa peruba-han yang signifikan terhadap penegakan hukum dengan tujuan untuk mencapai dan mewujudkan keadilan bagi seluruh masyarakat. Urgensi perlu dilakukan pembaharuan KUHAP, pertimbangan sosiologis karena KUHAP dapat mencerminkan produk yang bersumber dari sistem nilai yang hidup dan berkembang dalam masyarakat. Selain itu pertimbangan lainnya dapat mengadaptasi perkembangan yang terjadi di dunia Internasional tanpa harus menghilangkan nilainilai nasional suatu bangsa (Asri Yusuf,2013:1). Kekurangan dan kelemahan- kelemahan yang terdapat dalam hukum acara pidana (KUHAP) baik ditelaah secara filosofis yang kurang mencerminkan rasa keadilan, ditelaah secara yuridis kurang memberikan kepastian hukum, tentu perlu dibenahi secara terstruktur dan sistemik, untuk itulah beberapa pasal yang ada dalam hukum acara pidana (KUHAP) ada yang dihilangkan yang tidak sesuai dengan tuntutan hukum yang ada pada saat ini dan ada pasal- pasal penambahan yang disesuai-kan dengan perkembangan hukum saat ini. Urgensi lainnya yang menyebabkan perlunya dilakukan pembaharuan/perubahan KUHAP, baik substansi maupun rumusan yang terdapat didalamnya adalah didorong distimulasi oleh banyaknya ruang abu- abu pada tingkat penyelidikan, penyidikan dan prapenuntutan, yang oleh para oknum aparat penegak hukum yang nakal dimanfaatkan untuk kepentingan ekonomi pribadinya, maka sudah sepantasnya hukum acara pidana (KUHAP perlu segera disempurnakan, diperbaiki /direvisi disesuaikan dengan tututan nasional dan perkembangan global, sehingga KUHAP yang diperbaharui secara langsung maupun tidak langsung dapat menjawab tuntutan masyarakat pencari keadilan, untuk melindungi hak- hak azasinya dan membatasi secara tegas dan jelas kewenangan aparat penegak hukum dalam menjalankan fungsi dan wewenangnya, supaya tidak bertindak sewenang- wenang, yang pada akhirnya dapat menciptakan kepastian hukum dan keadilan dalam proses penegakan hukum di negara Indonesia ini.

Hal-hal yang baru dalam perubahan KUHAP seperti kehadiran lem-baga hakim komisaris yang menggantikan kedudukan lembaga prape-radilan, yang tugasnya memberikan penilaian keabsahan penangkapan, penahanan yang dilakukan penyidik, yang dianggap belum aspiratif me-nyerap tuntutan dan perkembangan hukum saat ini, penyesuaian jangka waktu lamanya penahanan, dihapuskannya jenis- jenis penahanan kota dan rumah dan hanya ada satu penahanan rumah tahanan negara, dihapuskannya fungsi Rupbasan (rumah tempat penyimpanan benda- benda sitaan). Selain itu, dihapuskannya lembaga pemeriksaan koneksitas, karena terpisahnya lembaga peradilan militer dengan peradilan umum, terkecuali ditentukan lain dan lainnya, diharapkan dapat memberikan kepastian, keadilan, ketertiban dan menjawab tuntutan dan perkembangan hukum saat ini.

\section{SIMPULAN}

Urgensi dilakukan pembaharuan hukum acara pidana nasional di Indonesia yang lebih responsif, karena hukum acara pidana (KUHAP) dipandang tidak sesuai lagi dengan perubahan sistem ketatanegaraaan dan perkembangan hukum dalam masyarakat, terutama dalam praktik penanganan perkara tindak pidana yang menjadi petugas para penegak hukum untuk menyelesaikan perkaranya secara baik dan adil, dan yang kedua perkembangan hukum dan perubahan peta politik yang dibarengi dengan perkembangan ekonomi, transportasi dan tehnologi yang global berpengaruh pula terhadap makna dan keberadaan substansi KUHAP, sehingga perlu dilakukan pembaruan dengan hukum acara pidana yang lebih akomodatif, responsif dan aspiratif. Dalam rangka penegakan hukum yang berorientasi kepastian hukum dan berdimensi keadilan. Rancangan KUHAP harus dapat memberikan perlindungan dan pengakuan terhadap hak- hak azasi dan membatasi tindakan sewenang- wenang aparat pene-gak hukum dalam penyelesaian dan penanganan perkara tindak pidana dan dapat beradabtasi dengan tuntutan global, sesuai dengan konvensi yang sudah diratifikasi oleh Indonesia.

\section{DAFTAR PUSTAKA}

Amin, Rahman, Penyidikan POLRI Dalam Sistem Peradilan Pidana Ditinjau Dari Aspek Pembaharuan Hukum Pidana, blongspot.com, 2014.

Atmasasmita, Romli, Globalisasi Kejahatan Bisnis, Kencana Prena-da Media : Jakarta, 2010.

Dimyati,Khudzaifah, Problema Globalisasi, Muhammadyah University Surakarta, 2001.

Djafar, Wahyudi, Reforrmasi KUHAP, nasional.kompas.com, 2015.

Hamzah, Andi, Pengantar Hukum Acara Pidana Indonesia, Aksara : Jakarta, 1987.

Huda, Chairul, Reformasi Hukum Acara Pidana Indonesia Dalam RKUHAP, blogspot.com,2009. 
Nawawi Arief, Barda, Sistem Peradilan dan Realitas Penegakan Hukum, Jakarta, 2014.

Poernomo, Bambang, Pandangan Azas- azas Umum Hukum Acara Pidana, Liberty : Jogyakarta, 1999.

Rahardjo, Satjipto, Hukum Progresif, Genta Publishing : Jakarta, 2009.

Reksodiputro, Mardjono, Hak Azasi Manusia Dalam Sistem Peradilan Pidana, Lembaga Kriminologi UI : Jakarta, 1996.

Soesilo, R, KUHAP Dengan Segala Penjelasannya, Politeia : Bogor, 2004.

Susanto Ginting, Miko, Mendorong Pembaharuan Kitab Undang- undang Hukum Acara Pidana, Parlemen.net,2014.

Suyudi, Aria, Mengais Harapan di Ujung Pengabdian, Pusat Studi Hukum dan Kebijakan, Jakarta, 2009.

Triatmojo, Sudibyo,Pelaksanaan Penahanan dan Kemungkinan Yang Ada Dalam KUHAP, Alumni : Bandung, 1986.

Yahya, M. Harahap, Pembahasan, Permasalahan dan Penerapan KUHAP, Sinar Grafika :Jakarta, 2004.

Yudowidagdo, Hendrastanto, Kapita Selekta Hukum Acara Pidana,Bina Aksara : Jakarta, 1998.

Yusuf,Asri, Alasan Pembaharuan Hukum Pidana, wordpress.com, 2013.

---- Kitab Undang- undang Hukum Acara Pidana Undang- undang Nomor 8 Tahun 1981.

----- Penjelasan Rancangan KUHAP, Kemenkumham, 2012.

-----Komite Masyarakat Sipil Untuk Pembaharuan KUHAP, Argumen Dibalik RUU KUHAP, kuhap.or.id. 